\title{
GENETIC DIVERSITY ASSESSMENT AMONG TALL COCONUT PALM ${ }^{1}$
}

\author{
KAMILA MARCELINO BRITO SOBRAL ${ }^{2}$, MANOEL ABÍLIO DE QUEIROZ ${ }^{3}$, CARLOS ALBERTO DA SILVA \\ LEDO $^{4}$, CARINA MENDES LOIOLA $^{5}$, JÉSSICA BARROS ANDRADE ${ }^{2}$, SEMÍRAMIS RABELO RAMALHO \\ RAMOS $^{5 *}$
}

\begin{abstract}
The tall coconut (Cocos nucifera L.) has great socioeconomic importance in Brazil and was first introduced on the coast of the north-eastern region, where it has been exploited in a semi-extractivist manner. The goal of this study was to quantify the genetic divergence between accessions introduced and preserved at the International Coconut Genebank for Latin America and the Caribbean, estimate the efficiency of descriptors used in the discrimination of the accessions, and indicate the essential descriptors for the activities of characterisation and evaluation. The accessions used were: Polynesia Tall; Tonga Tall; West African Tall; Rennel Tall; Rotuma Tall; Vanuatu Tall; Malayan Tall and Brazilian Tall Praia-do-Forte. Thirty-five quantitative descriptors recommended for the species were used. Genetic divergence was estimated by the Mahalanobis's generalised distance and the cluster analysis was performed using the unweighted pair group method with arithmetic mean (UPGMA). The relative importance of the descriptors was measured according to Singh and Jolliffe's methods, and the variables were selected taking into consideration the matching information in the two methods, eliminating those that were discarded in the two procedures. The agronomic characteristics indicated that the first canonical variable explained $90.25 \%$ of total variance. The most efficient descriptors for detecting the genetic divergence were: fruit equatorial circumference; nut polar and equatorial circumference; quantity of liquid endosperm; total fruit weight; nut weight; stem height; girth of stem at 1,5m height; number of leaflets; and number of bunches. The most dissimilar accessions according to the agronomic characteristics were Rotuma Tall and West African Tall, which can be primarily indicated as genitors for the formation of segregating populations in breeding programmes.
\end{abstract}

Keywords: Cocos nucifera L.. Genetic resources. Genetic variability. Germplasm.

\section{DIVERSIDADE GENÉTICA ENTRE ACESSOS DE COQUEIRO-GIGANTE}

RESUMO - O coqueiro-gigante (Cocos nucifera L.) tem grande importância socioeconômica no Brasil e foi primeiramente introduzido no litoral da região Nordeste, onde é explorado de forma semi-extrativista. O objetivo desse trabalho foi quantificar a divergência genética entre os acessos introduzidos e conservados no Banco Internacional de Germoplasma de Coco para América Latina e Caribe, verificar a eficiência dos descritores utilizados na discriminação dos acessos e indicar os essenciais para etapas de caracterização e avaliação. Foram avaliados os acessos: Gigante-da-Polinésia; Gigante-de-Tonga; Gigante-do-Oeste-Africano; Gigante-de-Rennel; Gigante-de-Rotuma; Gigante-de-Vanuatu; Gigante-da-Malásia e Gigante-da-Praia-doForte. Utilizou-se 35 descritores quantitativos recomendados para a espécie. A divergência genética foi estimada pela distância generalizada de Mahalanobis e o agrupamento foi realizado pelo método UPGMA. A importância relativa dos descritores foi mensurada de acordo com os métodos de Singh e Jolliffe e as variáveis foram selecionadas levando-se em consideração as informações coincidentes nos dois métodos, eliminando-se aqueles que foram descartados em ambos os procedimentos. Utilizando as características agronômicas detectou-se que a primeira variável canônica explicou 90,25\% da variância total. Os descritores mais eficientes para detecção da divergência genética foram: circunferência equatorial do fruto, circunferência polar e equatorial da noz, volume do endosperma, peso total do fruto e noz, altura de estipe, circunferência do estipe a $150 \mathrm{~cm}$ do solo, número de folíolos e número de cachos por planta. Os acessos mais dissimilares pelas características agronômicas foram o Gigante-de-Rotuma e Gigante-do-Oeste-Africano, os quais podem ser prioritariamente indicados como genitores para a formação de populações segregantes em programas de melhoramento.

Palavras-chave: Cocos nucifera L.. Recursos genéticos. Variabilidade genética. Germoplasma.

\footnotetext{
${ }^{*}$ Corresponding author

${ }^{1}$ Received for publication in 06/19/2016; accepted in 04/11/2017.

Paper extracted from the doctoral thesis of the first author.

${ }^{2}$ Department of Biological Sciences, Universidade Estadual de Feira de Santana, Feira de Santana, BA, Brazil; milambrito@hotmail.com, jessicabandrade@hotmail.com.

${ }_{3}^{3}$ Department of Technology and Social Sciences, Universidade do Estado da Bahia, Juazeiro, BA, Brazil; manoelabiliomaq@gmail.com.

${ }^{4}$ Embrapa Mandioca e Fruticultura, Cruz das Almas, BA, Brasil; carlos.ledo@embrapa.br.

${ }^{5}$ Embrapa Tabuleiros Costeiros, Aracaju, SE, Brasil; carina_loiola@yahoo.com.br, semiramis.ramos@embrapa.br.
} 


\section{INTRODUCTION}

The coconut tree (Cocos nucifera L.) is an exotic species which, being useful for the Portuguese colonizers in their expeditions to America, was introduced in the State of Bahia, north-eastern region of Brazil in 1553 (HARRIES, 1977). The natural populations are integrated into the landscapes of coastal areas and the common coconut variety found in Bahia is very similar to other varieties seen in Jamaica, South America, and West and East Africa (ROMNEY; DIAS, 1979), as well as to other varieties belonging to the Indo-Atlantic group (MARTINEZ et al., 2009).

Brazil has 271,000 hectares cultivated with coconut tree, spread across almost the entire national territory (FAOSTAT, 2016). About $70 \%$ of coconut production is located in the north-eastern coastal strip and part of the northern region. However, the areas of production are still mostly exploited in a semi-extractivist manner. The cultivation has low average productivity due to the cultivation of non-improved genotypes that feature low productive potential and production instability, as well as susceptibility to biotic and abiotic stresses.

In addition, the genetic basis of the germplasm grown in Brazil is narrow, as well as the preserved germplasm. However, it is worth mentioning that a Brazilian coconut breeding programme began in the 1980s. To that end, accessions were introduced to create the genebank of the species (ARAGÃO et al., 1999). Due to numerous technical limitations for safe movement of the germplasm, the genebank is composed of a small number of accessions. However, it is the second most important genebank of the Americas, the main one of South America, and the only one in Brazil, consisting of accessions from different geographical regions of the world and collected on the coast of the northeast region of Brazil. In 2006, the genebank was linked to the International Coconut Genetic Resources Network (COGENT-BIOVERSTY) and, thus, elevated to the international category, being named International Coconut Genebank for Latin America and the Caribbean (ICG-LAC) (LOIOLA et al., 2016).

Although Brazil is the fourth largest world producer, there is still a small demand on the part of the public and private sectors in the search for new genotypes and, consequently, genetic variability. In addition, the cultivation still features problems caused by pests and diseases, such as the threat of lethal yellowing disease (LYD), classified in Brazil as Pest $A_{I}$ by the Ministry of Agriculture, Livestock and Food Supply (MAPA). This disease has caused serious losses in Mexico, Jamaica, and other Caribbean regions (OROPEZA et al., 2005). Thus, the knowledge about the characteristics of preserved accessions, as well as the estimation of the genetic variability, will increase the possibility of use and meeting the needs of preventive breeding programmes in the country.

The objectives of the present study were to quantify the genetic divergence among accessions of tall coconut preserved in the ICG-LAC, and estimate the efficiency of descriptors used in the discrimination of the accessions to indicate the essential descriptors for the activities of characterisation and evaluation of coconut germplasm.

\section{MATERIAL AND METHODS}

From May to August 2015, eight accessions of tall coconut preserved at the ICG-LAC located in the Betume Experimental Field, Neópolis city, State of Sergipe, Brazil $\left(10^{\circ} 26^{\prime} \mathrm{S} ; 36^{\circ} 32^{\prime} \mathrm{W}\right.$; and $28 \mathrm{~m}$ altitude) were evaluated.

According to the Köppen classification, the climate of the Neopolis is A's type (tropical rainy with dry summer). The average annual rainfall is $1,270 \mathrm{~mm}$, of which $71.8 \%$ occurs during the rainy season (April to September) and 28.2\% during the dry season (October to March). The average annual temperature is around $24.7{ }^{\circ} \mathrm{C}$ and the average relative humidity is $76.67 \%$. The soil of the experimental field is classified as quartzarenic neosol with low natural fertility. The fertilisation was carried out according to the soil and foliar analyses. The plants were grown under unirrigated conditions. The culture treatments consisted of chemical crowning and mechanised undergrowth cleaning between planting lines.

In the experimental design, the accessions were arranged in random blocks with three replicates and 32 useful plants aged 33 years per plot, at a spacing of $9 \times 9 \times 9 \mathrm{~m}$ in equilateral triangle, except for the Vanuatu Tall and Malayan Tall, which had only two replicates due to losses in the installation of the genebank. For the activity of evaluation, 10 plants of each accession were selected, namely: Polynesia Tall (PYT); Brazilian Tall Praia-do-Forte (BRTPF); Tonga Tall (TONT); West African Tall (WAT); Rennel Island Tall (RIT); Rotuman Tall (RTMT); Vanuatu Tall (VTT) and Malayan Tall (MLT) .

To evaluate the vegetative descriptors, the leaf number 14 in each plant was used. Three fruits/ plant/accession/replicate for the evaluation of fruit components were used. Inflorescences were marked and the fruits were harvested eleven months after fruiting.

The quantitative descriptors present in the descriptive list (IPGRI, 1995), were used, namely: $\mathrm{HS}=$ stem height $(\mathrm{m}) ; \mathrm{CS} 20=$ girth of stem at $20 \mathrm{~cm}$ 
above soil level $(\mathrm{cm}) ; \mathrm{CS} 150=$ girth of stem at $1.5 \mathrm{~m}$ height (m); HLS11 = height of 11 leaf scars $(\mathrm{cm})$; $\mathrm{NGL}=$ number of green leaves (unit); LL = leaf length $(\mathrm{m}) ; \mathrm{PL}=$ petiole length $(\mathrm{m}) ; \mathrm{PW}=$ petiole width $(\mathrm{cm}) ; \quad \mathrm{PT}=$ petiole thickness $(\mathrm{mm})$; $\mathrm{NL}=$ number of leaflets (unit); LLT = leaflet length (m); LW - leaflet width $(\mathrm{cm})$; NFF = number of female flowers (unit); NI = number of inflorescences; FED = fruit equatorial diameter $(\mathrm{cm})$; $\mathrm{FPD}=$ fruit polar diameter $(\mathrm{cm}) ; \mathrm{FPC}=$ fruit polar circumference $(\mathrm{cm}) ; \mathrm{FEC}=$ fruit equatorial circumference $(\mathrm{cm}) ; \mathrm{NPD}=$ nut polar diameter $(\mathrm{mm}) ; \quad \mathrm{NED}=$ nut equatorial diameter $(\mathrm{mm})$; $\mathrm{NPC}=$ nut polar circumference $(\mathrm{cm}) ; \mathrm{NEC}=$ nut equatorial circumference $(\mathrm{cm}) ; \mathrm{VLE}=$ quantity of liquid endosperm $(\mathrm{ml})$; $\mathrm{SSC}=$ soluble solid content of endosperm ( $\left.{ }^{\circ} \mathrm{Brix}\right) ; \mathrm{pH}=\mathrm{pH}$ of the endosperm $(\mathrm{pH}) ; \mathrm{TWF}=$ total fruit weight $(\mathrm{kg}) ; \mathrm{FWWLE}=$ fruit weight without liquid endosperm $(\mathrm{kg}), \mathrm{SAW}=$ solid albumen weight $(\mathrm{kg})$; EDW = endocarp weight $(\mathrm{kg})$; $\mathrm{NW}=$ nut weight $(\mathrm{kg})$; EPW = epicarp weight $(\mathrm{kg})$; $\mathrm{TSA}=$ thickness solid albumen $(\mathrm{mm})$; $\mathrm{TE}=$ thickness endocarp $(\mathrm{mm}) ; \mathrm{NF}=$ number of fruits (unit); and NB = number of bunches (unit).

The selection of descriptors was performed by means of two procedures: (1) direct selection, through which it was excluded the descriptors that presented the highest weighting coefficient in absolute value (eigenvector) in the canonical variable of smaller eigenvalue, starting from the last component to one whose eigenvalue did not exceed 0.70 (JOLLIFFE, 1972, 1973); and (2) the method proposed by Singh (1981), taking into account the relative contribution of each descriptor for genetic divergence. Variables with values below $4 \%$ were considered as likely to be discarded. The analyses of canonical variables and selection of variables were carried out using the GENES software (CRUZ, 2013). The final disposal of the variables was carried out taking into consideration the matching information of the two methods, eliminating those that had been discarded in the two procedures.

In order to assist the decision regarding the disposal of a particular variable, it was estimated the partial Pearson correlation coefficients among the discarded and the selected variables. The partial correlation coefficients were obtained from the matrix of sums of squares and products from the residue obtained in the multivariate analysis of variance using the SAS statistical package (SAS INSTITUTE, 2003).

For the selected variables, a cluster analysis was performed, considering the Mahalanobis's generalised distance. The hierarchical clustering was obtained from the genetic distance matrix using the unweighted pair group method with arithmetic mean (UPGMA) (SNEATH; SOKAL, 1973). All the cluster analyses were performed using the GENES software (CRUZ, 2013). The consistency of the clusters was determined by the cophenetic correlation coefficient according to Sokal and Rohlf (1962). The significance of the cophenetic correlation coefficients was calculated using Mantel test with 1,000 permutations (MANTEL, 1967). The cut-off point was defined using the pseudo-t2 method obtained with the NbClust package of the $\mathrm{R}$ computer program (CHARRAD et al., 2015).

\section{RESULTS AND DISCUSSION}

The analysis of the agronomic characteristics by means of canonical variables explained about $90.25 \%$ of total variance in the first variable. Among the descriptors used FEC, NPC, NEC, VLE, TWF, NW were those that contributed the most to this variation (Tables 1 and 2). It was possible to observe that there was consistency in the selected descriptors to determine the genetic divergence, mainly by size and weight of fruit, which are characteristics of great commercial importance (Table 2).

Table 1. Eigenvalue, total variance (\%), and total accumulated variance (\%) for each canonical variable using agronomic characteristics.

\begin{tabular}{rrrr}
\hline Canonical Variable & Eigenvalue & $\begin{array}{c}\text { Total } \\
\text { Variance (\%) }\end{array}$ & $\begin{array}{c}\text { Total Accumulated } \\
\text { Variance }(\%)\end{array}$ \\
\hline VC1 & 51303.07 & 90.25 & 90.25 \\
VC2 & 3419.81 & 6.02 & 96.27 \\
VC3 & 1809.98 & 3.18 & 99.45 \\
VC4 & 221.78 & 0.39 & 99.84 \\
VC5 & 77.59 & 0.14 & 99.98 \\
VC6 & 8.43 & 0.01 & 100.00 \\
VC7 & 2.19 & 0.00 & 100.00 \\
\hline
\end{tabular}


Table 2. Relative contribution of diversity characteristics according to Singh (1981) and the analysis of the weighting coefficients obtained by canonical variables of agronomic characteristics.

\begin{tabular}{lrcr}
\hline Variable $^{*}$ & Singh & VC 1 (90.16\%) & VC 2 (5.64\%) \\
\hline FPD & 1.88 & 16.26 & 8.03 \\
FPC & 4.65 & 21.14 & -18.51 \\
FEC & 5.69 & -41.94 & -0.63 \\
NPC & 7.50 & -43.62 & 2.10 \\
NEC & 17.83 & 78.70 & -8.60 \\
VLE & 15.11 & -40.85 & 10.62 \\
SSC & 0.16 & 0.15 & 2.80 \\
pH & 1.08 & -14.40 & -0.95 \\
TWF & 2.57 & 39.27 & 13.94 \\
NW & 15.32 & -36.60 & -4.89 \\
TSA & 6.95 & 7.07 & 3.83 \\
TE & 0.77 & -6.95 & 1.84 \\
NED & 20.50 & 24.39 & -3.54 \\
\hline
\end{tabular}

*FPD: fruit polar diameter $(\mathrm{cm})$; FPC: fruit polar circumference $(\mathrm{cm})$; FEC: fruit equatorial circumference $(\mathrm{cm})$; NPC: nut polar circumference $(\mathrm{cm})$; NEC: nut equatorial circumference $(\mathrm{cm})$; VLE: quantity of liquid endosperm (ml); SSC: soluble solid content of endosperm ( $\left.{ }^{\circ} \mathrm{BRIX}\right) ; \mathrm{pH}$ : $\mathrm{pH}$ of the endosperm; TWF: total fruit weight $(\mathrm{kg})$; NW: nut weight $(\mathrm{kg})$; TSA: thickness solid albumen $(\mathrm{mm})$; TE: thickness endocarp $(\mathrm{mm})$; NED: nut equatorial diameter $(\mathrm{mm})$.

Using the vegetative descriptors, it was observed that the first canonical variable was responsible for $81.73 \%$ of the total variance, and the descriptors HS, CS150, NL and NB were those that contributed the most to the divergence among the evaluated accessions. These descriptors are related to the development, nutrition and production of plants, and they can be measured quickly when compared with the fruit descriptors of low-cost, effective for the differentiation of accessions (Tables 3 and 4). According to Cruz, Ferreira and Pessoni (2011), since there is a concentration of large proportion of total variance in the first variables (above $80 \%$ ); it is possible to study genetic divergence by means of geometric distances between genotypes in scatter charts.

As well as the results presented, other works have also used canonical variables in order to evaluate the descriptors responsible for the divergence variance. Ribeiro, Soares and Ramalho (1999) assessed accessions of tall coconut and obtained a total variation of $95.12 \%$ among the first three canonical variables. However, it can be observed a wide use of canonical variables, probably due to the lack of an experimental design, or because the data do not indicate normality. For this reason, other techniques, such as that of main components, were used (ZIZUMBO-VILLARREAL; COLUNGA-GARCÍAMARÍN, 2001; LOIOLA, 2014; OYOO et al., 2015; YAO et al., 2015).

Table 3. Eigenvalue, total variance (\%), and total accumulated variance (\%) for each canonical variable using vegetative characteristics.

\begin{tabular}{rrcc}
\hline $\begin{array}{c}\text { Canonical } \\
\text { Variable }\end{array}$ & Eigenvalue & $\begin{array}{c}\text { Total } \\
\text { Variance (\%) }\end{array}$ & $\begin{array}{c}\text { Total Accumulated } \\
\text { Variance }(\%)\end{array}$ \\
\hline VC1 & 75587.57 & 81.73 & 81.73 \\
VC2 & 14789.02 & 15.99 & 97.72 \\
VC3 & 2086.19 & 2.26 & 99.98 \\
VC4 & 10.63 & 0.01 & 99.99 \\
VC5 & 4.57 & 0.00 & 100.00 \\
VC6 & 2.65 & 0.00 & 100.00 \\
VC7 & 1.15 & 0.00 & 100.00 \\
VC8 & 0.00 & 0.00 & 100.00 \\
\hline
\end{tabular}


Table 4. Relative contribution of diversity characteristics according to Singh (1981) and the analysis of the weighting coefficients, obtained by canonical variables of vegetative characteristics.

\begin{tabular}{lrcc}
\hline Variable $^{*}$ & Singh & VC 1 (92.12\%) & VC 2 (7.28\%) \\
\hline HS & Sij (\%) & 13.63 & 1.89 \\
CS20 & 25.23 & -6.33 & 0.84 \\
CS150 & 5.03 & 15.29 & -1.77 \\
HLS11 & 28.00 & 2.58 & 3.02 \\
NGL & 0.41 & 8.13 & -5.25 \\
LL & 8.66 & -8.33 & -11.13 \\
PL & 3.88 & 2.13 & 7.63 \\
NL & 0.36 & 10.74 & -1.83 \\
LLT & 12.81 & -3.96 & 6.03 \\
LW & 3.44 & -1.32 & 2.39 \\
PT & 1.39 & -6.21 & -6.79 \\
NF & 5.73 & 1.21 & 11.86 \\
NB & 1.95 & 16.50 & -4.25 \\
\hline
\end{tabular}

$* \mathrm{HS}=$ stem height $(\mathrm{m}) ; \mathrm{CS} 20=$ girth of stem at $20 \mathrm{~cm}$ above soil level $(\mathrm{cm}) ; \mathrm{CS} 150=$ girth of stem at $1.5 \mathrm{~m}$ height $(\mathrm{m})$; HLS11 = height of 11 leaf scars $(\mathrm{cm})$; NGL = number of green leaves (unit); $\mathrm{LL}=$ leaf length $(\mathrm{m}) ; \mathrm{PL}=$ petiole length $(\mathrm{m}) ; \mathrm{NL}=$ number of leaflets (unit); $\mathrm{LLT}=$ leaflet length (m); LW - leaflet width (cm); PT = petiole thickness (mm); NF: number of fruit (unit); NB: number of bunches (unit).

Canonical variables analyses, when used in studies on genetic divergence, are aimed at identifying similar genotypes in scatter charts (CRUZ; FERREIRA; PESSONI, 2011). The results obtained in the present study allowed a two-dimensional graphic visualisation of the accessions of tall coconut using the first and the second canonical variables (Figures 1 and 2).

The comparison between the two scatter charts indicated that the accessions did not cluster equally, resulting in the formation of different clusters. This fact was due to the characteristics analysed, which were quantitative, controlled by many genes, and had strong environmental interference. Although the clusters were not exactly the same, there were few changes, because among the eight accessions assessed, only the MLT and the TONT were not matched in the two groups of data. Figure 1 show that the accessions PYT, RTMT, TONT remained closer to each other, and the BRTPF, WAT, VTT, MLT and RTI formed a second group. On the other hand, the morphological descriptors indicated that the accessions of PYT, RTMT and MLT were more similar, and the accessions BRTPF, TONT, VTT, WAT and RIT formed a second group (Figure 2).

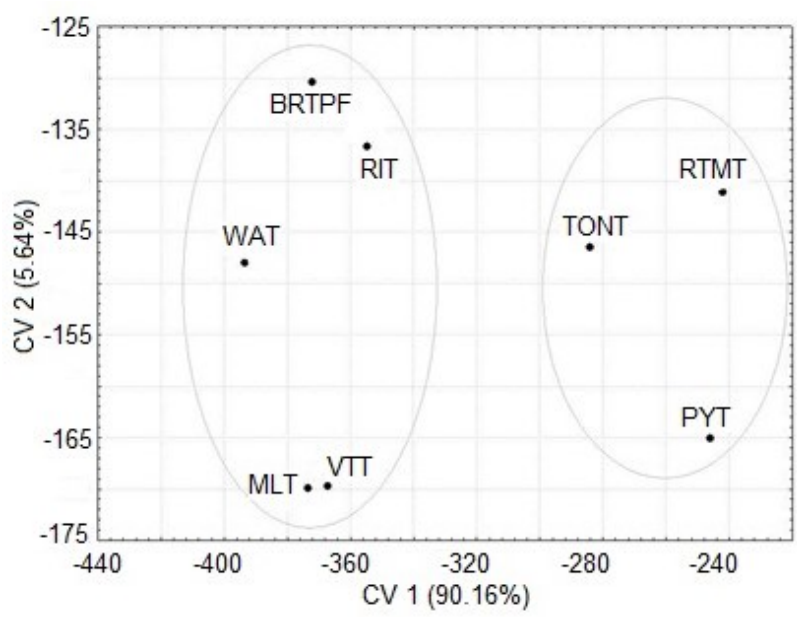

Figure 1. Score dispersion in eight accessions of tall coconut with respect to the first two canonical variables (CV1 and CV2), and accumulated variance (\%), based on agronomic characteristics.

Rev. Caatinga, Mossoró, v. 31, n. 1, p. 28 - 39, jan. - mar., 2018 


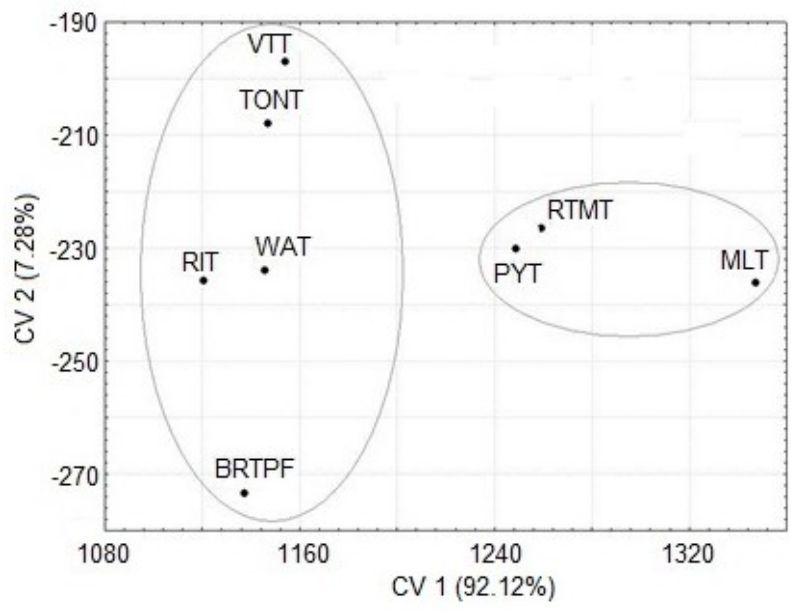

Figure 2. Score dispersion in eight accessions of tall coconut with respect to the first two canonical variables (CV1 and CV2), and accumulated variance (\%), based on vegetative characteristics.

The following descriptors were discarded: FED, FWWLE, SAW, EDW, EPW, NDP, PT, PW and NL. According to Singh's coefficient (1981), the descriptor VLE was the most important among the selected descriptors $(26.70 \%)$, followed by NEC $(17.16 \%)$, HS (17.04\%), and NPC (12.85\%) (Table $5)$.

It is worth mentioning the permanence of the descriptors HLS11 and LW, because, although they were discarded by Singh (1981) and Jolliffe's (1972, 1973) criterion, they are important to infer about plant development (Table 5). While the descriptor HLS11 is related to plant development with respect to the stem growth rate-which is more intense in the early years of the plant-the measurement of the $\mathrm{LW}$ is related to a good plant development and nutritional status.

The partial correlations established were significant and positive for the majority of the descriptors evaluated and demonstrated that the disposal of selected characteristics would not cause loss of information in case they were not used in the next evaluations made in the genebank, given that the selected descriptors had correlations of $1 \%$ of significance with the discarded descriptors for the majority of the correlations. The $\mathrm{pH}$ and SSC did not show significant difference with the discarded descriptors. These characteristics are chemical and do not have a specific relationship with size and weight of the fruit; however, they are important to determine the quality of the water (Table 6).

By means of the partial Pearson correlation, it was possible to observe that the descriptors relating to size, weight and thickness of the fruit components were correlated, indicating that using a smaller number of descriptors can reduce time and cost and, at the same time, provide the required information about the studies on genetic divergence between accessions of tall coconut. The same fact was observed with respect to the vegetative characteristics PT and PW, which were significant with respect to the descriptors relating to the foliar structure (Table 7).

For the characteristics relating to vegetative descriptors, the closest accessions were the TONT and MLT, and the most distant were RIT and VTT (Table 9). The divergence found between the accessions of RTMT and WAT can be explained by the geographic origin, because they belong to distinct populations, given that the WAT is from the Ivory Coast and the RTMT from the Fiji Islands. The same fact occurs with the divergence between the RIT and VTT, which are original from the South Pacific, but from different countries, the RIT is from the Solomon Islands and the VTT from Vanuatu.

From a predictive perspective, it can be affirmed that the accessions with major dissimilarities with respect to those of Indo-Atlantic origin can assist in the selection of progenitors for important crossbreeding for genetic breeding programs in Brazil, for example, crossbreeding aimed at preventive breeding for lethal yellowing. This disease is caused by a phytoplasma and severely affects coconut production in some areas of the Americas and the Caribbean, such as those located in Jamaica, Florida, Belize, Cuba, Haiti, Honduras, Dominican Republic, and Mexico (MARINHO; BATISTA; MILLER, 2002; OROPEZA et al., 2005; MYRIE et al., 2014), since reports have indicated that this disease has been decimating many plantations. Despite the fact that Brazil has already initiated studies and contingency measures, if the dissemination rate continues growing, the phytoplasma can reach South America. Some studies conducted with the production of hybrids have obtained good results relating to resistance, for example, crossbreeding between the Sri Lanka Dwarf and Vanuatu Tall (DARE et al., 2010). 
K. M. B. SOBRAL et al.

Table 5. Pre-selected and selected variables based on Singh and Jolliffe's methods.

\begin{tabular}{|c|c|c|c|c|}
\hline \multirow{3}{*}{ Variables } & \multicolumn{3}{|c|}{ Pre-selected } & \multirow{3}{*}{ Selected } \\
\hline & \multicolumn{2}{|c|}{ Singh } & \multirow{2}{*}{$\begin{array}{c}\text { Jolliffe } \\
\text { Discarded } \\
\end{array}$} & \\
\hline & $\mathrm{Sij}(\%)$ & Discarded & & \\
\hline FDP & 0.28 & D3 & $\mathrm{S}$ & $\mathrm{S}$ \\
\hline FED & 3.02 & D10 & D9 & $\mathrm{D}$ \\
\hline FPC & 7.44 & $\mathrm{~S}$ & D5 & $\mathrm{S}$ \\
\hline FEC & 4.65 & $\mathrm{~S}$ & D10 & S \\
\hline NPC & 12.85 & S & $\mathrm{S}$ & $\mathrm{S}$ \\
\hline NEC & 17.16 & $\mathrm{~S}$ & D11 & S \\
\hline VLE & 26.70 & $\mathrm{~S}$ & D4 & $\mathrm{S}$ \\
\hline $\mathrm{SSC}$ & 0.86 & D6 & S & S \\
\hline $\mathrm{pH}$ & 0.20 & D1 & S & S \\
\hline TWF & 7.37 & $\mathrm{~S}$ & D3 & $\mathrm{S}$ \\
\hline FWWLE & 3.98 & D12 & D7 & $\mathrm{D}$ \\
\hline SAW & 1.47 & D7 & D6 & $\mathrm{D}$ \\
\hline EDW & 0.24 & $\mathrm{D} 2$ & D12 & $\mathrm{D}$ \\
\hline NW & 4.36 & $\mathrm{~S}$ & D2 & $\mathrm{S}$ \\
\hline EPW & 2.39 & D9 & D8 & $\mathrm{D}$ \\
\hline TSA & 0.62 & D4 & $\mathrm{S}$ & $\mathrm{S}$ \\
\hline $\mathrm{TE}$ & 0.64 & D5 & S & S \\
\hline NPD & 3.90 & D11 & D1 & $\mathrm{D}$ \\
\hline NED & 1.86 & D8 & $\mathrm{S}$ & $\mathrm{S}$ \\
\hline HS & 17.04 & $\mathrm{~S}$ & $\mathrm{~S}$ & S \\
\hline CS20 & 5.20 & $\mathrm{~S}$ & D1 & S \\
\hline CS150 & 2.61 & D5 & $\mathrm{S}$ & $\mathrm{S}$ \\
\hline HLS11 & 3.18 & D7 & D2 & $\mathrm{D}$ \\
\hline NGL & 2.02 & D3 & $\mathrm{S}$ & $\mathrm{S}$ \\
\hline LL & 6.41 & S & D3 & $\mathrm{S}$ \\
\hline PL & 4.72 & $\mathrm{~S}$ & D6 & $\mathrm{S}$ \\
\hline PT & 3.96 & D8 & D7 & $\mathrm{D}$ \\
\hline PW & 1.51 & D1 & D4 & $\mathrm{D}$ \\
\hline NL & 3.11 & D6 & $\mathrm{S}$ & $\mathrm{S}$ \\
\hline LLT & 1.76 & D2 & $\mathrm{S}$ & $\mathrm{S}$ \\
\hline LW & 2.31 & D4 & D8 & $\mathrm{D}$ \\
\hline $\mathrm{NF}$ & 10.81 & S & $\mathrm{S}$ & $\mathrm{S}$ \\
\hline NB & 5.71 & $\mathrm{~S}$ & D5 & $\mathrm{S}$ \\
\hline
\end{tabular}

$\mathrm{S}=$ selected, $\mathrm{D}=$ discarded $* \mathrm{FPD}=$ fruit polar diameter $(\mathrm{cm}) ; \mathrm{FED}=$ fruit equatorial diameter $(\mathrm{cm}) ; \mathrm{FPC}=$ fruit polar circumference $(\mathrm{cm}) ; \mathrm{FEC}=$ fruit equatorial circumference $(\mathrm{cm}) ; \mathrm{NPC}=$ nut polar circumference $(\mathrm{cm})$; $\mathrm{NEC}=$ nut equatorial circumference $(\mathrm{cm}) ; \mathrm{VLE}=$ quantity of liquid endosperm $(\mathrm{ml}) ; \mathrm{SSC}=$ soluble solid content of endosperm $\left({ }^{\circ} \mathrm{Brix}\right) ; \mathrm{pH}=\mathrm{pH}$ of the endosperm $(\mathrm{pH}) ; \mathrm{TWF}=$ total fruit weight $(\mathrm{kg}) ; \mathrm{FWWLE}=$ fruit weight without liquid endosperm $(\mathrm{kg}), \mathrm{SAW}=$ solid albumen weight $(\mathrm{kg})$; EDW = endocarp weight $(\mathrm{kg})$; $\mathrm{NW}=$ nut weight $(\mathrm{kg}) ; \mathrm{EPW}=$ epicarp weight $(\mathrm{kg}) ; \mathrm{TSA}=$ thickness solid albumen $(\mathrm{mm})$; TE $=$ thickness endocarp $(\mathrm{mm})$; $\mathrm{NPD}=$ nut polar diameter $(\mathrm{mm}) ; \mathrm{NED}=$ nut equatorial diameter $(\mathrm{mm}) ; \mathrm{HS}=$ stem height $(\mathrm{m})$; CS20 = girth of stem at $20 \mathrm{~cm}$ above soil level $(\mathrm{cm})$; CS150 = girth of stem at $1.5 \mathrm{~m}$ height $(\mathrm{m})$; HLS11 = height of 11 leaf scars $(\mathrm{cm}) ; \mathrm{NGL}=$ number of green leaves (unit); $\mathrm{LL}=$ leaf length $(\mathrm{m}) ; \mathrm{PL}=$ petiole length $(\mathrm{m}) ; \mathrm{PT}=$ petiole thickness $(\mathrm{mm}) ; \mathrm{PW}=$ petiole width $(\mathrm{cm}) ; \mathrm{NL}=$ number of leaflets (unit); LLT = leaflet length (m); LW - leaflet width (cm $\mathrm{NF}=$ number of fruits (unit); and $\mathrm{NB}=$ number of bunches (unit). 
Table 6. Partial correlation coefficients between the discarded and the selected variables based on agronomic characteristics.

\begin{tabular}{lcccccc}
\hline \multirow{2}{*}{ Selected $*$} & \multicolumn{5}{c}{ Discarded } \\
\cline { 2 - 7 } & FED & FWWLE & SAW & EDW & EPW & NPC \\
\hline FPD & $0.66^{* *}$ & $0.64^{* *}$ & $0.51^{\mathrm{ns}}$ & $0.66^{* *}$ & $0.75^{* *}$ & $0.43^{\mathrm{ns}}$ \\
FPC & $0.83^{* *}$ & $0.83^{* *}$ & $0.59^{*}$ & $0.82^{* *}$ & $0.79^{* *}$ & $0.57^{*}$ \\
FEC & $0.94^{* *}$ & $0.91^{* *}$ & $0.82^{* *}$ & $0.92^{* *}$ & $0.73^{* *}$ & $0.83^{* *}$ \\
NPC & $0.85^{* *}$ & $0.89^{* *}$ & $0.90^{* *}$ & $0.90^{* *}$ & $0.58^{*}$ & $0.92^{* *}$ \\
NEC & $0.85^{* *}$ & $0.78^{* *}$ & $0.94^{* *}$ & $0.88^{* *}$ & $0.41^{\mathrm{ns}}$ & $0.97^{* *}$ \\
VLE & $0.93^{* *}$ & $0.84^{* *}$ & $0.89^{* *}$ & $0.93^{* *}$ & $0.52^{*}$ & $0.90^{* *}$ \\
SSC & $-0.23^{\mathrm{ns}}$ & $-0.20^{\mathrm{ns}}$ & $-0.05^{\mathrm{ns}}$ & $-0.14^{\mathrm{ns}}$ & $-0.44^{\mathrm{ns}}$ & $0.09^{\mathrm{ns}}$ \\
pH & $0.11^{\mathrm{ns}}$ & $-0.04^{\mathrm{ns}}$ & $0.28^{\mathrm{ns}}$ & $0.10^{\mathrm{ns}}$ & $0.02^{\mathrm{ns}}$ & $0.25^{\mathrm{ns}}$ \\
TWF & $0.94^{* *}$ & $0.96^{* *}$ & $0.74^{* *}$ & $0.95^{* *}$ & $0.82^{* *}$ & $0.76^{* *}$ \\
NW & $0.88^{* *}$ & $0.84^{* *}$ & $0.95^{* *}$ & $0.92^{* *}$ & $0.50^{\mathrm{ns}}$ & $0.95^{* *}$ \\
TSA & $0.08^{\mathrm{ns}}$ & $-0.06^{\mathrm{ns}}$ & $0.49^{\mathrm{ns}}$ & $-0.01^{\mathrm{ns}}$ & $-0.36^{\mathrm{ns}}$ & $0.42^{\mathrm{ns}}$ \\
TE & $0.47^{\mathrm{ns}}$ & $0.58^{*}$ & $0.27^{\mathrm{ns}}$ & $0.60^{*}$ & $0.49^{\mathrm{ns}}$ & $0.29^{\mathrm{ns}}$ \\
NED & $0.80^{* *}$ & $0.78^{* *}$ & $0.96^{* *}$ & $0.84^{* *}$ & $0.37^{\mathrm{ns}}$ & $0.98^{* *}$ \\
\hline
\end{tabular}

**and *significant to 1 and $5 \%$, respectively, by the teste of t.; ${ }^{\text {ns }}$ not significant. *FPD: fruit polar diameter $(\mathrm{cm})$; FPC: fruit polar circumference $(\mathrm{cm})$; FEC: fruit equatorial circumference $(\mathrm{cm})$; NPC: nut polar circumference $(\mathrm{cm})$; NEC: nut equatorial circumference $(\mathrm{cm})$; VLE: quantity of liquid endosperm (ml); SSC: soluble solid content of of endosperm ( $\left.{ }^{\circ} \mathrm{BRIX}\right)$; $\mathrm{pH}: \mathrm{pH}$ of the endosperm; TWF: total fruit weight $(\mathrm{kg})$; NW: nut weight $(\mathrm{kg})$; TSA: thickness solid albumen $(\mathrm{mm})$; TE: thickness endocarp (mm); NED: nut equatorial diameter $(\mathrm{mm}) ; \mathrm{FED}=$ fruit equatorial diameter $(\mathrm{cm})$; FWWLE = fruit weight without liquid endosperm $(\mathrm{kg}), \mathrm{SAW}=$ solid albumen weight $(\mathrm{kg})$; $\mathrm{EDW}=$ endocarp weight $(\mathrm{kg}) ; \mathrm{EPW}=$ epicarp weight $(\mathrm{kg}) ; \mathrm{NPC}=$ nut polar circumference $(\mathrm{cm})$.

Table 7. Partial correlation coefficients between the discarded and the selected variables based on vegetative characteristics.

\begin{tabular}{lllll}
\hline \multirow{2}{*}{ Selected* } & \multicolumn{3}{c}{ Discarded } \\
\cline { 2 - 5 } & HLS11 & PT & PW & LW \\
\hline HS & $0.22^{\mathrm{ns}}$ & $-0.29^{\mathrm{ns}}$ & $0.09^{\mathrm{ns}}$ & $-0.33^{\mathrm{ns}}$ \\
CS20 & $0.13^{\mathrm{ns}}$ & $0.24^{\mathrm{ns}}$ & $0.37^{\mathrm{ns}}$ & $-0.21^{\mathrm{ns}}$ \\
CS150 & $-0.06^{\mathrm{ns}}$ & $0.08^{\mathrm{ns}}$ & $-0.30^{\mathrm{ns}}$ & $0.06^{\mathrm{ns}}$ \\
NGL & $-0.07^{\mathrm{ns}}$ & $0.55^{*}$ & $0.54^{\mathrm{ns}}$ & $0.25^{\mathrm{ns}}$ \\
LL & $-0.09^{\mathrm{ns}}$ & $0.56^{*}$ & $0.73^{* *}$ & $-0.11^{\mathrm{ns}}$ \\
PL & $-0.31^{\mathrm{ns}}$ & $0.67^{* *}$ & $0.58^{*}$ & $0.12^{\mathrm{ns}}$ \\
NL & $0.31^{\mathrm{ns}}$ & $0.26^{\mathrm{ns}}$ & $0.60^{\mathrm{ns}}$ & $0.26^{\mathrm{ns}}$ \\
LLT & $0.26^{\mathrm{ns}}$ & $0.18^{\mathrm{ns}}$ & $0.49^{\mathrm{ns}}$ & $0.14^{\mathrm{ns}}$ \\
NF & $-0.29^{\mathrm{ns}}$ & $0.42^{\mathrm{ns}}$ & $0.80^{* *}$ & $-0.20^{\mathrm{ns}}$ \\
\hline
\end{tabular}

**and *significant to 1 and $5 \%$, respectively, by the teste of $\mathrm{t} t ;{ }^{\mathrm{ns}}$ not significant. $* \mathrm{HS}=$ stem height (m); CS20 = girth of stem at $20 \mathrm{~cm}$ above soil level $(\mathrm{cm}) ; \mathrm{CS} 150=$ girth of stem at $1.5 \mathrm{~m}$ height $(\mathrm{m}) ; \mathrm{NGL}=$ number of green leaves (unit); $\mathrm{LL}=$ leaf length $(\mathrm{m}) ; \mathrm{PL}=$ petiole length (m); NL = number of leaflets (unit); LLT = leaflet length (m); NF = number of fruits (unit); HLS11 = height of 11 leaf scars $(\mathrm{cm}) ; \mathrm{PT}=$ petiole thickness $(\mathrm{mm}) ; \mathrm{PW}=$ petiole width (cm); LW - leaflet width (cm). 
Among all the accessions evaluated up to now, those originating in Southeast Asia exhibit higher resistance to lethal yellowing, suggesting that the ancestors of these populations had contracted the same disease or another similar one and, thus, became resistant or tolerant (BAUDOUIN et al., 2009). Due to the genetic proximity between the WAT and all populations of tall coconut established in Brazil (RIBEIRO et al., 2010; LOIOLA, 2014; LOIOLA et al., 2016) there is a need for strategic planning involving studies on plant pathology, molecular genetics, and breeding for assessing and obtaining cultivars and hybrids that are resistant to lethal yellowing. In case this disease occurs in Brazil, large losses in plantations across the country will be probably observed.

Crossbreeding can also be carried out on the basis of commercial characteristics, such as weight of fruit and nut, solid albumen, and water volume. According to the study conducted by Ribeiro et al.
(2000), the accession of RTMT featured large fruits weighing around $1,543 \mathrm{~g}$, had great fruit composition, with high albumen weight (536 g), and greater weight of copra $(309 \mathrm{~g})$. The accession of WAT featured fruits weighting $1,041 \mathrm{~g}$, only surpassing the accession of VTT (909 g); however, it featured greater epicarp percentage $(146.4 \%)$. The endosperm was little thick, but rich in oil and proteins, and was more homogeneous. These accessions exhibited greatest genetic distances according to agronomic characteristics (Table 8), and had commercial characteristics, such as, greater weight of copra, high weight of albumen, weight of epicarp, and high oil content, which can jointly or separately meet the industry and agriculture demands. In this way, the crossing between these two accessions WAT and RTMT can strengthen breeding programmes for the production of new hybrids with promising commercial characteristics in Brazil.

Table 8. Mahalanobis's generalised distance in eight accessions of tall coconut based on agronomic characteristics.

\begin{tabular}{lrrrrrrr}
\hline Access & BRTPF & TONT & WAT & RIT & RTMT & VTT & MLT \\
\hline PYT & \multirow{2}{*}{17278.13} & 1836.60 & 22050.32 & 13277.92 & 624.70 & 14739.44 & 16430.46 \\
BRTPF & & 8265.74 & 958.54 & 1840.68 & 17253.38 & 1686.45 & 2180.40 \\
TONT & & & 12074.13 & 5809.71 & 1878.81 & 7633.07 & 8703.52 \\
WAT & & & & 2602.22 & 23137.42 & 1254.48 & 1363.33 \\
RIT & & & & & 13380.27 & 2279.14 & 1753.79 \\
RTMT & & & & & & 16569.93 & 18258.08 \\
VTT & & & & & & & \\
\hline
\end{tabular}

*Polynesia Tall (PYT); Brazilian Tall -Praia-do-Forte (BRTPF); Tonga Tall (TONT ); West African Tall (WAT); Rennel Island Tall (RIT); Rotuman Tall (RTMT); Vanuatu Tall (VTT); and Malayan Tall (MLT)

Table 9. Mahalanobis's generalised distance in eight accessions of tall coconut based on vegetative characteristics

\begin{tabular}{lccrrrr}
\hline Access* & TONT & WAT & \multicolumn{1}{c}{ RIT } & \multicolumn{1}{c}{ RTMT } & \multicolumn{1}{c}{ VTT } & \multicolumn{1}{c}{ MLT } \\
\hline PYT & \multirow{2}{*}{14343.02} & 10925.10 & 10771.50 & 16636.52 & 179.59 & 10081.94 \\
BRTPF & & 4392.53 & 1707.94 & 1917.53 & 17142.04 & 6250.30 \\
TONT & & & 764.47 & 1667.24 & 13064.16 & 283.76 \\
WAT & & & 707.30 & 13055.03 & 1560.08 \\
RIT & & & & 19478.08 & 2863.09 \\
RTMT & & & & & 11899.35 \\
\hline
\end{tabular}

*Polynesia Tall (PYT); Brazilian Tall - Praia-do-Forte (BRTPF); Tonga Tall (TONT ); West African Tall (WAT); Rennel Island Tall (RIT); Rotuman Tall (RTMT); Vanuatu Tall (VTT); and Malayan Tall (MLT).

The analysis of hierarchical clustering was carried out using the UPGMA method based on Mahalanobis's generalised distance (D2ii'). The dendrogram obtained showed high cophenetic correlation coefficient $\left(r=0.8671^{* *}\right)$, validating the clustering method used. The UPGMA method allowed creating a dendrogram (Figure 3 ) consisting of two clusters that were similar to those of the scatter chart by canonical variables, in which the first group (G1) was formed by the accessions of PYT, RTMT and TONT, and the second group (G2) was formed by the accessions of BRTPF, WAT, VTT, MLT and RIT. 


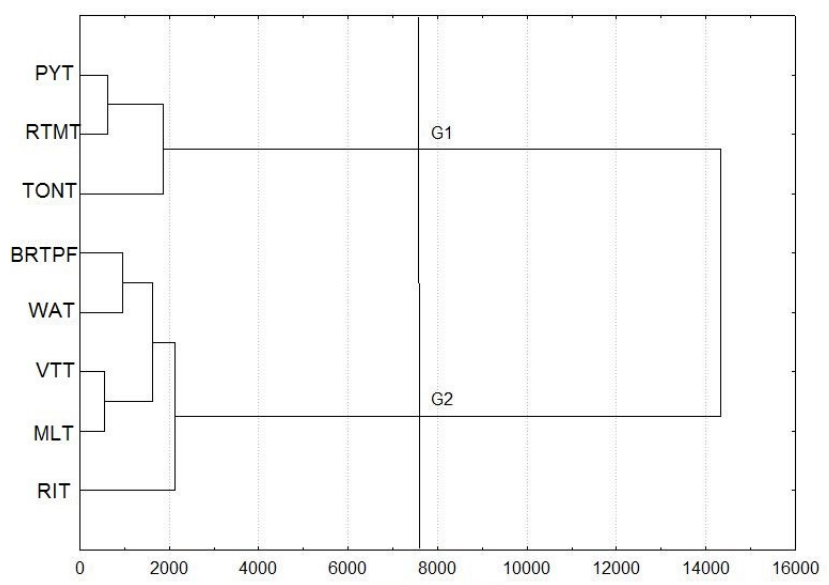

Figure 3. Dendrogram based on Mahalanobis's generalised distance and the UPGMA method for eight accessions of tall coconut based on agronomic characteristics.

The vegetative descriptors were used to analyse the same accessions and obtained a new dendrogram (Figure 4) that differed from the first (Figure 3) generated by the agronomic descriptors. Two groups were formed: the G1 group with the accessions of PYT, RTMT and MLT; and the G2 group with the accessions of BRTPF, TONT, VTT, WAT and RIT. This result was similar to that found by the dispersion of canonical variables for this group of data (Figure 4). However, despite having differentiated the accessions and exhibited similarity with the results of the canonical variables, it is worth pointing out that the value for the cophenetic correlation was $r=0.7008^{* *}$, which was considered poor (SOKAL; ROHLF, 1962).

Perera et al. (2003) assessed 94 varieties of coconut palm by means of microsatellite markers and observed that the accessions had been distributed into different groups, in which the accessions of RIT, VTT, MLT, and TONT were similar and were clustered together; however, the accessions of RTMT and WAT were in separate clusters. Thus, there were differences between the results obtained from the vegetative evaluation of fruit components (carpological) and those obtained by Perera et al.
(2003). This fact occurred because the use of molecular techniques provides information relating to the sharing of genes and the genetic distance, whereas studies assessing phenotypic characterisation show the gene expression. Therefore, since many of these characteristics are quantitative, they are subjected to strong environmental influence.

These studies complement each other. They provide a set of predictive information about the accessions, informing about the genetic proximity and how they will develop in the environment. Thus, they provide and make information available to breeders and those working on improvement programmes in order to promote a more extensive use of the accessions.

For breeding works, it is important to use accessions with greater genetic divergence, better commercial and agronomic characteristics. In addition, these accessions should be resistant to pests and diseases. In the present work, it was possible to observe the genetic divergence between the preserved accessions through vegetative and agronomic characteristics, demonstrating that the selection is possible for intra-varietal crosses.

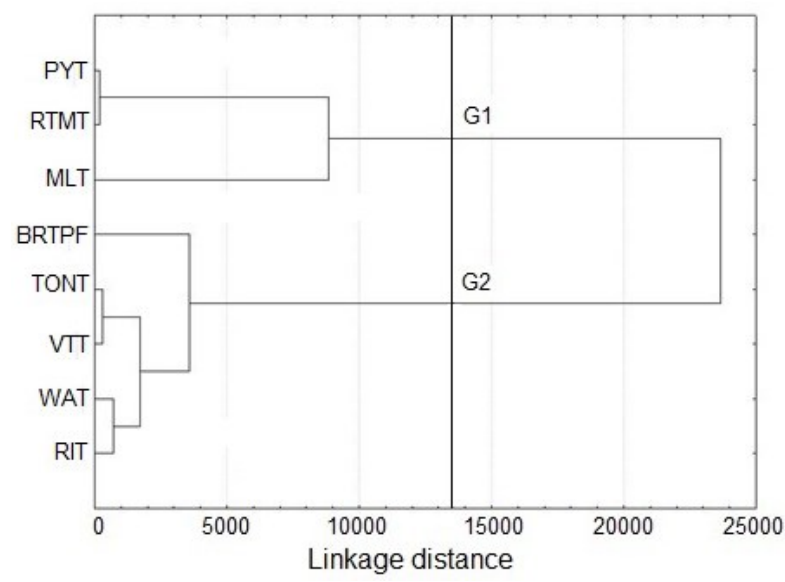

Figure 4. Dendrogram based on Mahalanobis's generalised distance and the UPGMA method for eight accessions of tall coconut based on vegetative characteristics. 


\section{CONCLUSIONS}

The selected descriptors were efficient in determining the genetic divergence among accessions of tall coconut palm. The descriptors listed as essential and recommended were: fruit equatorial circumference; nut polar and equatorial circumference; quantity of liquid endosperm; total fruit weight; nut weight; stem height; girth of stem at $1,5 \mathrm{~m}$ height; number of leaflets; and number of bunches. The most dissimilar accessions due to the agronomic characteristics were the Rotuma Tall and the West African Tall, which can primarily be indicated as genitors for genetic breeding programmes.

\section{REFERENCES}

ARAGÃO, W. M. et al. Seleção de cultivares de coqueiro para diferentes ecossistemas do Brasil. In: QUEIROZ, M. A.; GOEDERT, C. O.; RAMOS, S. R. R. (Eds.). Recursos genéticos e melhoramento de plantas para o Nordeste brasileiro. Petrolina: Embrapa Semiárido, 1999. Disponível em: <http:// www.cpatsa.embrapa.br:8080/catalogo/livrorg/ coco.pdf>. Acesso em: 24 abr. 2016.

BAUDOUIN, L. et al. General overview of genetic research and experimentation on coconut varieties tolerant/resistant to Lethal Yellowing. Oilseeds and Fats, Crops and Lipid, Les Ulis, v. 16, n. 2, p. 127 131, 2009.

CHARRAD, M. et al. NbClust: An examination of indices for determining the number of clusters. $R$ package version 1.4. Disponível em: $<$ https://cran.rproject.org/web/packages/NbClust/index.html $>$. Acesso em: 20 jan. 2015.

CRUZ, C. D.; FERREIRA, F. M.; PESSONI, L. A. Biometria Aplicada ao Estudo da Diversidade Genética. 1. ed. Viçosa, MG: UFV, 2011. 620 p.

CRUZ, C. D. GENES - A Software Package for Analysis in Experimental Statistics and Quantitative Genetics. Acta Scientiarum, Maringá, v. 35, n. 3, p. 271-276, 2013.

DARE, D. et al. Evaluation of some basic traits of a promising coconut hybrid: Sri Lankan green dwarf crossed to Vanuatu tall (SGD x VTT). Journal of Science and Technology, Kumasi, v. 30, n. 3, p. 914,2010 .

FAOSTAT. Culturas ano 2014. Disponível em: $<$ http://faostat.fao.org/site/567/DesktopDefault.aspx? PageID=567\#ancor $>$. Acesso em: 10 mar. 2016.
HARRIES, H. C. The Cape Verde region: (14991549): the key to coconut in the western hemisphere? Turrialba, Turrialba, Costa Rica, v. 27, n. 3, p. 227 $231,1977$.

INTERNATIONAL PLANT GENETIC RESOURCES INSTITUTE - IPGRI. Descritors for Coconut (Cocos nucifera L.). Rome, Italy, 1995, 68 p.

JOLLIFFE, I. T. Discarding variables in a principal component analysis. I. Artificial data. Applied Statistics, London, v. 21, n. 2, p. 160-173, 1972.

JOLLIFFE, I. T. Discarding variables in a principal component analysis. II: real data. Journal of the Royal Statistical Society Series C - Applied Statistics, London, v. 22, n. 1, p. 21-31, 1973.

LOIOLA, C. M. Diversidade genética em coqueiro -gigante (Cocos nucifera L.) por meio de marcadores microssatélites e características morfoagronômicas. 2014. 100 f. Dissertação (Doutorado em Fitotecnia: Área de Concentração em Agricultura Tropical) - Universidade Federal Rural do Semiárido, Mossoró, 2014.

LOIOLA, C. M. et al. Genetic relationships among tall coconut palm (Cocos nucifera L.) accessions of the International Coconut Genebank for Latin America and the Caribbean (ICG-LAC), evaluated using microsatellite markers (SSRs). PLoS ONE, San Francisco, v. 11, n. 3, p. 1-7, 2016.

MANTEL, N. The detection of disease clustering and generalized regression approach. Cancer Research, Birmingham, v. 27, n. 2, p. 209-220, 1967.

MARINHO, V. L. A.; BATISTA, M. F.; MILLER, R. Praga quarentenária A1 amarelecimento letal do coqueiro "Coconut Lethal Yellowing”. Brasília, DF: Embrapa Recursos Genéticos e Biotecnologia, 2002. 4 p. (Embrapa Recursos Genéticos e Biotecnologia. Comunicado técnico, 73).

MARTINEZ, R. T. et al. Characterization of the genetic diversity of the Tall coconut (Cocos nucifera L.) in the Dominican Republic using microsatellite (SSR) markers. Tree Genetics \& Genomes, New York, v. 6, n. 1, p. 73-81, 2009.

MYRIE, W. A. et al. First report of lethal yellowing disease associated with subgroup 16SrIV-A phytoplasmas in Antigua, West Indies. New disease Reports, London, v. 29, n. 12, p. 12, 2014.

OROPEZA, C. et al. Coconut lethal yellowing. In: BATUGAL, P.; RAMANATHA RAO, V.; OLIVER, J. (Eds.). Coconut Genetic Resources, Malaysia: 
International Plant Genetic Resources Institute, 2005. p. $349-363$.

OYOO, M. E. et al. In-situ morphological characterization of coconut in the Coastal Lowlands of Kenya. African Journal of Plant Science, Ebène, v. 2, n. 2, p. 65-74, 2015.

PERERA, L. et al. Studying genetic relationships among coconut varieties/populations using microsatellite markers. Euphytica, Wageningen, v. 132, n. 1, p. 121-128, 2003.

RIBEIRO, F. E.; SOARES, A. R.; RAMALHO, M. A. P. Divergência genética entre populações de coqueiro gigante do Brasil. Pesquisa Agropecuária Brasileira, Brasília, v. 34, n. 9, p. 1615-1622, 1999.

RIBEIRO, F. E. et al. Ecótipos de coqueiro gigante no Brasil. Aracaju, SE: EMBRAPA-CPATC, 2000. p. 25.

RIBEIRO, F. E. et al. Population structures of Brazilian tall coconut (Cocos nucifera L.) by microsatellite markers. Genetics and Molecular Biology, Ribeirão Preto, v. 33, n. 4, p. 696-702, 2010.

ROMNEY, D. H.; DIAS, B. C. Coconut varieties in Bahia state. In: Session of the FAO technical working party on coconut production, protection and processing, 5. FAO, 1979. p. 4.

SAS INSTITUTE. SAS Technical Report. SAS/ STAT software: Changes and Enhancement, Release 9.0, Cary NC: SAS Institute. 2003.

SINGH, D. The relative importance of characters affecting genetic divergence. The Indian Journal of Genetic and Plant Breeding, New Delhi, v. 41, n. 2, p. 237-245, 1981.

SNEATH, P. H.; SOKAL, R. R. Numerical taxonomy: The principles and practice of numerical classification. San Francisco: W. H. Freeman, 1973. 573 p.

SOKAL, R. R.; ROHLF, F. J. The comparison of dendrograms by objective methods. Taxon, Berlin, v. 11, n. 2 , p. 33-40, 1962.

ZIZUMBO-VILLARREAL, D.; COLUNGAGARCÍAMARÍN, P. Morpho-physiological variation and phenotypic plasticity in Mexican populations of coconut (Cocos nucifera L,), Genetic Resources and Crop Evolution, Germany, v. 48, n. 6, p. 547-554, 2001.
YAO, S. D. M. et al. Fiabilité d'une liste minimale de descripteurs agromorphologiques recommandée par le COGENT dans l'étude de la diversité génétique du cocotier (Cocos nucifera L.). Journal of Animal \&Plant Sciences, Lahore, v. 26, n. 1, p. 4006-4022, 2015. 